\title{
WARTOŚCIOWANIE WYBRANYCH ROZWIĄZAŃ ILUSTRATORSKICH W KSIĄŻKACH DLA DZIECI PRZEZ STUDENTÓW WCZESNEJ EDUKACJI
}

\begin{abstract}
Streszczenie: Kontakt ze sztuką plastyczną i pierwsze doświadczenia w komunikacji wizualnej zapewniają dziecku książki obrazkowe i ilustrowane. Dlatego istotne jest, by miały one określone miejsce w codzienności dziecka i by zapewniały wartościowe pod względem poznawczym i estetycznym bodźce. Miejscem, gdzie małe dziecko może ich doświadczać obok przestrzeni domu rodzinnego - jest przedszkole, dlatego nauczyciele powinni posiadać kompetencje związane z wprowadzaniem wychowanka w świat dobrej ilustracji książkowej, a przede wszystkim wyrażać osobiste zaangażowanie w wartościowanie tego rodzaju tekstów kultury. W opracowaniu przedstawiono, jakie wartości ilustracji książkowych postrzegają i preferują osoby przygotowujące się do zawodu nauczyciela wczesnej edukacji. Badani wartościowali ilustracje wykonane w różnych konwencjach i stylistyce (realistycznej i fantastycznej, klasyczne i awangardowe) oraz wykonane różnymi technikami (malarskimi i graficznymi). Zgromadzony korpus leksykalny, dotyczący odczuć związanych z percepcją ilustracji książkowej, analizowano z perspektywy kategorii ocen dzieł malarskich oraz kategorii wartościowania leksykalnego, wyrażającego osobisty stosunek do percypowanych obrazów.
\end{abstract}

Słowa kluczowe: książka obrazkowa dla dzieci, książka ilustrowana dla dzieci, studenci pedagogiki, wartościowanie ilustracji

\section{WPROWADZENIE}

Rodzice i pedagodzy często są przekonani, że kontakt ze sztuką plastyczną można zapewnić dziecku dopiero wówczas, gdy jest ono gotowe do odwiedzenia galerii czy muzeum. Rzadko natomiast zdają sobie sprawę, że estetyczna jakość najbliższego otoczenia dziecka, a więc ład i harmonia wokół niego, kolorystyka pomieszczeń, jakość wykonania i barwy przedmiotów, zabawek, którymi ono manipuluje i bawi 
się, nie tylko stanowią bodźce percepcyjne niezbędne do kształtowania wyobrażeń i myślenia, ale także wzmagają lub osłabiają wrażliwość na ich różnorodność oraz stanowią podstawy kształtowania się nawyków dążenia do kontaktu z określoną estetyką. Przedmiotami, które jako jedne z pierwszych trafiają do rąk dziecka i które oddziałują na nie nie tylko bodźcami dotykowymi, ale przede wszystkim dzięki wzrokowi, są książki obrazkowe ${ }^{1}$ i ilustrowane $e^{2}$. Wprowadzają one małego odbiorcę - za pomocą środków wizualnych - w system znaków i symboli kultury, przygotowując go do roli świadomego i twórczego eksploratora. Szczególną wartość w tym kontekście mają książki o walorach artystycznych.

Doświadczanie piękna dobrej ilustracji książkowej, jej unikatowego edytorstwa i koncepcji graficznej może stanowić dla odbiorcy wartość autoteliczną. Przeżywanie w kontakcie z książką tworzoną przez artystów ilustracji (i słowa pisanego) pozytywnych odczuć estetycznych, ale także intelektualnych (zaciekawienie, zaskoczenie), może skutkować dążeniem do podobnych doświadczeń.

Książka ilustrowana i obrazkowa stanowią medium enkulturacji, a przede wszystkim edukacji wizualnej i wychowania artystycznego. Zwłaszcza obecnie, a więc $w$ dobie społeczeństwa medialnego, to właśnie obrazy odgrywają niebagatelną i główną rolę w procesie komunikacji regulującej sprawy społeczne, kultury, gospodarcze i polityczne. Choć spostrzeżenie to brzmi banalnie, to nie można się z nim nie zgodzić, a tym bardziej ignorować tej kwestii w działalności dydaktyczno-wychowawczej w ogóle, a szczególnie w odniesieniu do rozmaitych tekstów kultury odwołujących się do percepcji wzrokowej. Umiejętność „czytania” obrazów, a dalej uczestnictwo w komunikacji wizualnej, czyli określone reagowanie na ich impulsy (zachowania, konstruowanie i rekonstruowanie wyobrażeń, myśli, sądów), kształtują się na drodze poznania reguł budowania komunikatów wizualnych i środków upośredniania kultury, takich jak wzory, symbole. Znaczenie edukacji wizualnej zdaje się rosnąć zwłaszcza ze względu na postnowoczesny charakter współczesnej kultury, nierzadko posługującej się obrazami stanowiącymi wieloznaczne

\footnotetext{
${ }^{1}$ W opracowaniu przyjęto za J. Wiercińską, iż „książka obrazkowa to taka postać książki dla dziecka, w której podstawowym elementem wypowiedzi jest obraz, gdzie strona wizualna, jeśli nie stanowi celu głównego, wiąże się z tekstem na zasadach równouprawnienia, gdzie pisarz i rysownik (jeśli to nie jest jedna i ta sama osoba) tak ściśle ze sobą współdziałają, że istnienie tekstu jest uwarunkowane obrazem i na odwrót” (Wiercińska 1986, s. 76). Szeroko na temat książki obrazkowej pisze M. Cackowska na łamach czasopisma „Ryms”: Czym jest książka obrazkowa? O pojmowaniu książki obrazkowej w Polsce -część I, „Ryms” 2009, nr 5, s. 5; część II, „Ryms” 2009, nr 6, s. 14-16; część III, „Ryms” 2009, nr 8, s. 12-13. Również K. Zabawa omawia zjawisko książki obrazkowej, proponując określanie jej mianem ikonotekstowej (2013, s. 63-79). K. Zabawa zajmuje się także problematyką książki ilustrowanej (2013, s. 44-62).

${ }^{2}$ Książką ilustrowaną określono wydawnictwo dla dzieci, którego podstawowym kodem komunikacji jest tekst pisany, zaś obrazy stanowią ilustrację jego treści (najczęściej wydarzeń, ich okoliczności i bohaterów).
} 
komunikaty, w których granice między tym, co rzeczywiste i nierzeczywiste, są coraz bardziej płynne, trudne do uchwycenia. Także nie bez znaczenia jest fakt, że rzeczywistość człowieka coraz częściej tworzą elementy, których nie może on doświadczyć osobiście, lecz jedynie przez konstruowane obrazy.

Każdy wytwór sztuki, w tym książka obrazkowa i ilustrowana dla dzieci, odzwierciedla istotne momenty aktualnego stanu kultury społeczeństwa, a zwłaszcza stosunku człowieka do rzeczywistości, w której funkcjonuje, sposobu jej postrzegania i interpretowania. Uczestniczenie w kulturze, korzystanie $\mathrm{z}$ jej rozmaitych wartości wymaga nie tylko poznania i rozumienia środków artystycznych służących jej tworzeniu, ale przede wszystkim postawy otwartości i gotowości do interpretowania jej elementów. Medium poznawania rzeczywistości materialnej i psychicznej, jakie niewątpliwie stanowi książka dla dziecka, powinno być doceniane szczególnie we wczesnej edukacji, kiedy to właśnie iluminacje budzą żywe zainteresowanie „czytelnika”, które dominuje nad zaciekawieniem tekstem.

Tymczasem rodzice często udostępniają dziecku książki wybrane przypadkowo, kierując się przy zakupie ilustracją widniejącą na okładce. Przy czym rzadko mają świadomość, jak oceniać warstwę ilustracyjną książek oraz jak wykorzystywać jej walory (co nie budzi zdziwienia i niezrozumienia). Osobami kompetentnymi pod tym względem powinni być nauczyciele wyposażeni w wiedzę pedagogiczno-psychologiczną, dotyczącą poznawczego i społeczno-emocjonalnego funkcjonowania dziecka, oraz metodyczne sprawności organizowania mu kontaktu z książką w ogóle (a także z ilustracją). Jednak nie sama wiedza o dziecku oraz opanowany warsztat metodyczny gwarantują, że nauczyciel będzie sięgał w pracy po książki z ilustracją o wysokich walorach artystycznych i z pasją aranżował opartą na nich aktywność dzieci. Niezwykle istotne wydają się także kompetencje w zakresie sztuki plastycznej oraz osobiste preferencje dotyczące wytworów sztuki plastycznej, której elementem jest ilustracja książkowa. Te natomiast kształtują się stopniowo, na kolejnych szczeblach edukacji.

W związku z tym starano się określić, jak studenci pierwszego roku kierunku pedagogika i specjalności pedagogika wczesnoszkolna i przedszkolna oceniają warstwę ilustracyjną książek dla dzieci, a zarazem odkryć ich preferencje rozwiązań graficznych wydawnictw dla najmłodszych. Osoby badane były $\mathrm{w}$ trakcie przygotowywania się do roli nauczyciela (I rok studiów licencjackich), a w przyszłości niejednokrotnie będą pośrednikiem między dzieckiem i książką, jak również osobą, od której nierzadko rodzice będą oczekiwali profesjonalnych porad w kwestii wyboru „lektury” dla dzieci. Kompetencje te, co prawda, będą zdobywali w kolejnych latach studiów (w toku realizacji przedmiotów metodycznych z zakresu pedagogiki przedszkolnej i wczesnoszkolnej, gdzie posiądą m.in. wiedzę i umiejętności związane $\mathrm{z}$ udostępnianiem i uprzystępnianiem dzieciom 
książek, jak również w ramach przedmiotów związanych z literaturą dziecięcą czy kształceniem polonistycznym), jednakże mogą i są one nabywane na podstawie elementarnej wiedzy młodych ludzi zarówno w dziedzinie sztuki literackiej, jak i plastycznej. Jeśli weźmiemy pod uwagę specjalność kształcenia, jaką wybrali badani, istotna - obok przygotowania w zakresie literatury dla dzieci (w sensie tekstów literackich) - wydaje się ich orientacja w dziedzinie sztuk wizualnych. Bowiem im młodszy odbiorca, tym większa jego koncentracja na graficznej warstwie książki (Baluch 2006, s. 152), jak również większa skłonność do akceptowania „słabych” artystycznie przedstawień ilustratorskich. W związku z tym nauczyciel wczesnej edukacji (a także student przygotowujący się do tej roli zawodowej) powinien wykazywać umiejętność analizowania i interpretacji tekstów wizualnych (ilustracji i obrazów w książce) w różnych ich aspektach (np. budowy formalnej czy znaczeniowej) i kontekstach (np. w kontekście tekstu, który współtworzy książkę, ale także w kontekście ich funkcji czy w odniesieniu do zjawisk całego dorobku kultury plastycznej).

\section{PROCEDURA BADAŃ I ANALIZY KORPUSU LEKSYKALNEGO}

Cele IV etapu edukacji (ponadgimnazjalnego) w przypadku przedmiotu wiedza o kulturze koncentrowały ${ }^{3}$ się wokół odbioru rozmaitych tekstów kultury, tworzenia wypowiedzi z użyciem różnych mediów (opartych na słowie, na obrazie statycznym i dynamicznym, dźwiękowym), a także na analizie i interpretacji praktyk kultury i dzieł sztuki (Podstawa programowa kształcenia ogólnego dla gimnazjów i szkót ponadgimnazjalnych...). Ponadto $\mathrm{w}$ treściach tego obszaru podstawy sygnalizowano, iż w efekcie realizacji przedmiotu wiedza o kulturze uczeń określa swoje zainteresowania, potrzeby i preferencje kulturalne oraz je uzasadnia. Oznacza to, że twórcy podstawy programowej zakładali, iż absolwent IV etapu edukacji miał opuszczać szkołę nie tylko z określoną wiedzą w zakresie dorobku kultury i umiejętnością jego rzeczowego komentowania, ale także z określonymi predylekcjami wobec jego elementów. Takie oczekiwania mogli wobec tego posiadać nauczyciele akademiccy $\mathrm{w}$ toku pracy dydaktycznej ze studentami. W związku $\mathrm{z}$ tym w planowaniu referowanych badań założono, iż badana populacja była gotowa do wyrażania rzeczowych opinii na temat prezentowanych ilustracji książkowych. Pytania, na które starano się uzyskać odpowiedź w toku badań, brzmiały:

${ }^{3}$ Osoby badane kończyły edukację szkolną przed wprowadzeniem reformy oświaty w Polsce, obowiązującej od 1 września 2017 roku. 
1. Jakie wartości przekazu wizualnego przypisują studenci ilustracjom w książkach dla dzieci?

2. Jaki stosunek do określonych ilustracji ujawnia się w leksyce wartościującej ilustracje książek dla dzieci? ${ }^{4}$

Wskaźnikami postrzeganych przez badanych wartości iluminacji książkowych będą kategorie formułowanych jednostek leksykalnych, uwzględniające obszar wartościowania. Zostały one wyznaczone na podstawie korpusu tekstowego publikacji dotyczących oceny dzieł malarskich (Choynowski 1967; Strzałecki 2006; Petruk, Waligórska 2013). W kategoryzacji pozyskanych jednostek leksykalnych wykorzystano czynniki oceny dzieł malarskich opracowane przez Mieczysława Choynowskiego (1967, s. 199-232) i Andrzeja Strzałeckiego (2006, s 229-250). Badacze wyłonili je w toku zastosowania dyferencjału malarskiego, a więc narzędzia służącego do ilościowej charakterystyki znaczenia konotatywnego przedmiotów i obiektów.

Wskaźnikiem stosunku badanych do prezentowanych ilustracji były z kolei kategorie formułowanych jednostek leksykalnych z uwzględnieniem konotacji o zabarwieniu pozytywnym, negatywnym lub obojętnym. W związku z tym odwołano się także do językoznawstwa, na gruncie którego rozważane jest zjawisko leksykalnego wartościowania. Elżbieta Laskowska określa je jako wewnętrzny proces, polegający na przypisywaniu przedmiotowi wartości (Laskowska 1992, s. 19). Wyjaśnia także, iż wartościowanie może się realizować w różnych podsystemach języka, a więc w leksyce, morfologii, składni, a także w intonacji. W opracowaniu skoncentrowano się na płaszczyźnie leksykalnej.

Grupę badanych stanowiło 67 studentów ${ }^{5}$, którym prezentowano ilustracje pochodzące z 4 książek dla dzieci ( 2 obrazkowych i 2 ilustrowanych). Polecenie kierowane do badanych brzmiało: „Za chwilę obejrzysz wybrane ilustracje książek dla dzieci. Opierając się na pierwszych spostrzeżeniach i wrażeniach, sformułuj określenie, które będzie odzwierciedlało Twoją ocenę prezentowanych ilustracji”. Ilustracje prezentowano dwukrotnie na dużym ekranie za pomocą rzutnika multimedialnego. Za pierwszym razem każdy obraz (po 4 ilustracje z każdej książki) wyświetlano przez 10 sekund. Za drugim ilustracje prezentowano także przez 10 sekund, przy czym po ekspozycji ilustracji każdego tytułu następowała 15 sekundowa przerwa umożliwiająca zapisanie przez badanych określeń, o które ich proszono. Korpus badawczy stanowiło więc 268 jednostek leksykalnych. Obej-

${ }^{4}$ Analiza wyników badań dotyczących tego pytania będzie w opracowaniu omówiona sygnalizacyjnie. Raport z badań dotyczących tej problematyki został przedstawiony w opracowaniu autorki The Lexical Evaluation of Children's Book Illustrations by Pedagogy Students (Centner-Guz 2016).

${ }^{5} \mathrm{~W}$ badaniach brali udział studenci I roku pedagogiki wczesnoszkolnej i przedszkolnej UMCS w roku akademicki 2013/2014. Były wśród nich 64 kobiety i 3 mężczyzn. 
mowały one 4 kategorie językowe: przymiotniki, rzeczowniki i rzadko wyrażenia przyimkowe oraz grupy imienne.

Wstępna analiza całości zgromadzonego materiału werbalnego, dokonana na podstawie wspomnianego wyżej korpusu tekstowego związanego z oceną dzieł malarskich, pozwoliła ustalić główne kategorie ocen ilustracji prezentowanych studentom. Kolejne określenia formułowane przez badanych porównywano z określeniami stanowiącymi przykłady czynników ocen reprodukcji malarskich. Formułowane przez studentów jednostki leksykalne, które nie pojawiały się jako egzemplifikacje określonych czynników we wskazanych źródłach, kategoryzowano na podstawie podobieństwa znaczeniowego z innymi, przykładowymi sformułowaniami. Analiza pozwoliła ustalić, iż studenckie wartościowanie leksykalne ilustracji dotyczyły następujących aspektów funkcjonowania przekazu wizualnego (ilustracji w książce dziecięcej):

- wartości artystycznych, a więc ogólnej oceny jego wartości, jego oryginalności, doniosłości, bogactwa środków wypowiedzi artystycznej, a także kunsztu ilustratora;

- wyrazu artystycznego związanego z próbą obiektywizacji cech stylistycznych wytworu plastycznego w stosunku do przeżywanych emocji, a więc z jego nastrojowością oraz metaforycznością/wewnętrzną komunikacją obrazu;

- budowy formalnej, czyli właściwości budowy wytworu plastycznego, jego wewnętrznej organizacji, uporządkowania, ładu (Strzałecki 2006, s. 245).

Wiele sformułowań studentów było pozbawionych konotacji wartościujących jakiekolwiek właściwości ilustracji. W tym wypadku badani wyliczali najczęściej środki plastyczne, którymi posłużył się ilustrator (np. „czerwone”, „kolorowe”, „symetryczne”, „kanciaste”). W analizach zamieszczonych poniżej tego typu wypowiedzi kategoryzowano jako brak ocen.

W badaniach wykorzystano 4 rodzaje ilustracji książkowych. W ich doborze kierowano się rozmaitością stosowanej konwencji ilustratorskiej, a także obiegowymi (opinie dzieci, dorosłych niekompetentnych w zakresie sztuki plastycznej) i profesjonalnymi ocenami (recenzje twórczości artystycznej w zakresie sztuki ilustratorskiej). Badanym studentom prezentowano po cztery ilustracje następujących książek:

1. Czerwony Kapturek z ilustracjami Kvety Pacovskiej ${ }^{6}$ (tekst: Bracia Grimm, Wydawnictwo Dwie Siostry, Warszawa 2008): Konwencję plastyczną tej publikacji należy uznać za awangardową, zwłaszcza w obszarze ilustrowa-

${ }^{6}$ K. Pacovska jest znaną i cenioną na arenie międzynarodowej czeską ilustratorką i graficzką, a także laureatką prestiżowej Nagrody im. Hansa Christiana Andersena w roku 1992. Ilustrowany przez nią Czerwony Kapturek otrzymał nagrodę główną w kategorii „Książki dla dzieci w wie- 
nia książek dla dzieci. Przejawia się ona głownie w stylu iluminacji, który z uwagi na formę ujęcia przedstawień należy sytuować na pograniczu figuratywności i abstrakcji.

2. Martynka poznaje ptaki z ilustracjami Marcela Marliera ${ }^{7}$ (tekst: Gilbert Delahaye, Wydawnictwo Papilon): Ilustracje do serii o Martynce są utrzymane w konwencji realistycznej. Niezwykła dbałość o precyzyjne określenie kształtów i szczegółów - zarówno przedmiotów i postaci, jak i elementów świata przyrody - nawiązuje do stylu naiwnego realizmu.

3. Prawdziwa bajka ilustrowana przez Martę Ignerską (tekst: Mikołaj Łoziński, Wydawnictwo Kultura Gniewu, Warszawa 2013): Graficzna warstwa książki nawiązuje do sztuki nowoczesnej. Ilustratorka posłużyła się podstawowymi kształtami, takimi jak koło, kwadrat, prostokąt, linia, a także formami nieposiadającymi nazw matematycznych. Obok nich wykorzystała schematyczne zarysy obiektów (tunel) i elementów otoczenia (góry) oraz ikonki (schemat postaci ludzkiej, stacji benzynowej).

4. Sposób na laleczkę z ilustracjami Anny i Lecha Stefaniaków (tekst: Maria Konopnicka, Wydawnictwo Sara, Warszawa 2011): Książka stanowi egzemplifikację bajkowej formuły ilustrowania, zbliżonej do estetyki kiczu? . Iluminacje charakteryzuje krzykliwość kolorów, idealizowanie form, a także powtarzalność schematów (wizerunki twarzy, sylwetki postaci można znaleźć w licznych innych tytułach wydawnictwa).

\section{WARTOŚCIOWANIE LEKSYKALNE ILUSTRACJI NOWOCZESNEJ (NAWIĄZUJĄCEJ DO ABSTRAKCJONIZMU GEOMETRYCZNEGO)}

Ilustracje Czerwonego Kapturka cechuje dynamiczna geometryzacja, która służy autorce do przedstawienia określonych (nie wszystkich) wydarzeń ujętych w narracji tekstowej. Wielokrotnie na stronicach lub całych rozkładówkach pojawia się wyolbrzymiony element nawiązujący w sposób symboliczny do istotnego zdarze-

ku od lat 5” w VII edycji (2008 rok) konkursu „Świat przyjazny dziecku”, który organizuje Komitet Ochrony Praw Dziecka.

${ }^{7}$ M. Marlier jest belgijskim ilustratorem, któremu przygotowywanie ilustracji do wielotomowej serii o Martynce przyniosło międzynarodową sławę.

${ }^{8}$ W 2013 roku książka otrzymała główną nagrodę graficzną Polskiej Sekcji IBBY za projekt graficzny i ilustracje.

9 Znamiennymi cechami zjawiska kiczu są: jarmarczność (tandeta i krzykliwość barw), akademizm (powtarzalność schematów, form), nierzetelność i bark prawdy (idealizacja). Właściwości kiczu z perspektywy wartościowania ilustracji w książkach dla dzieci oraz na podstawie koncepcji A. Banacha, syntetycznie charakteryzuje A. Boguszewska (2008, s. 243). 
nia (np. do tekstu dotyczącego połknięcia bohaterki baśni odnosi się kompozycja przedstawiająca głowę wilka, co sygnalizują jedynie zaznaczone na różowym tle takie elementy, jak: wyeksponowane, pełne ostrych zębów usta, oczy z czerwoną tęczówką oraz kolorowy „nos” w kształcie cienkiego prostokąta). Postacie utworu i elementy otoczenia wyłaniają się z prostych form geometrycznych, co sprawia wrażenie, jakby były konstruowane, a nie malowane.

Ilustratorka odrzuca świadomie koncepcję mimetyczną na rzecz „zabawy” kształtami. Ponadto łączy rozmaite techniki plastyczne (rysunkowe, malarskie, kolaż), tworząc w efekcie bogatą formę wypowiedzi plastycznej. Kolorystyka kolejnych ilustracji jest najczęściej zredukowana do czerwieni, czerni i błyszczącego srebra, jedynie elementy lasu zachowują właściwą sobie zieleń, a kwiaty wielobarwność.

Rozkład ilościowy formułowanych przez studentów określeń na temat ilustracji z Czerwonego Kapturka z uwzględnieniem przyjętych kategorii wartościowania zawarto w tabeli 1.

Tabela 1. Kategorie jednostek leksykalnych wartościujących ilustracje książki Czerwony Kapturek

\begin{tabular}{|c|c|c|c|c|}
\hline \multicolumn{2}{|c|}{ Kategoria oceny } & \multicolumn{2}{|c|}{$\mathbf{L}$} & $\%$ \\
\hline \multicolumn{2}{|c|}{ Wartość artystyczna } & \multicolumn{2}{|c|}{20} & 30 \\
\hline \multirow{2}{*}{ Wyraz artystyczny } & Nastrojowość & 6 & \multirow{2}{*}{22} & 22 \\
\hline & Metaforyczność & 16 & & 33 \\
\hline \multicolumn{2}{|l|}{ Budowa formalna } & \multicolumn{2}{|c|}{18} & 27 \\
\hline \multicolumn{2}{|c|}{ Brak ocen/wyliczanie elementów formalnych } & \multicolumn{2}{|c|}{7} & 10 \\
\hline
\end{tabular}

Źródło: badania własne

Jak widać, oceny studentów dotyczące ilustracji wykonanych w stylistyce nowoczesnej odnosiły się z podobną częstotliwością do trzech obszarów wartościowania wytworów plastycznych. Najwięcej jednostek leksykalnych (33\%) związanych było z wyrazem artystycznym ocenianych ilustracji, przy czym większość spośród nich dotyczyła oceny ich metaforyczności, pozostałe zaś odnosiły się do nastroju obrazów. Badani w tym przypadku najczęściej formułowali takie określenia, jak: „abstrakcja”, „ogólne”, „niejawne”, „dziwne” oraz „ciężkie”, „smutne”, „straszne”. Autorzy tego typu określeń koncentrowali się na stylistyce i wymowie emocjonalnej ilustracji (wynikającej z cech budowy formalnej ilustracji). Podobna liczba osób (30\%), ujmując w słowach wrażenie, jakie wywarły oglądane ilustracje, dokonywała ogólnej oceny ich wartości artystycznej. Przykładowe określenia brzmiały: „okropne”, „głupie”, „niefajne”, „nudne”, „zaskakujące”. Większość określeń świadczy o braku akceptacji i zainteresowania tego rodzaju rozwiązaniami graficznymi. 
Reakcje werbalne studentów wyrażały bardzo dobitnie niechęć obcowania z niekonwencjonalną ilustracją („okropne”), ale także brak zrozumienia dla sposobu ujęcia baśniowej rzeczywistości przez artystkę. Warto zauważyć, że stosowana przez badanych leksyka nierzadko pochodziła z obszaru mowy potocznej.

Także około $1 / 3$ jednostek leksykalnych formułowanych przez studentów odnosiła się do budowy formalnej ilustracji Czerwonego Kapturka. Badani koncentrowali się w ocenach na wewnętrznej organizacji percypowanych obrazów. Najczęściej odnotowywane określenia były następujące: „chaotyczne”, „nieczytelne”, „poplątane”, „zdezorganizowane”, „zagmatwane”, „zabałaganione”, „nowoczesne”. Widoczne jest podobieństwo odczuć respondentów formułujących oceny w kategorii „budowa formalna” wobec ilustracji Kvety Pacovskiej. Ci badani prawdopodobnie doświadczali w kontakcie z nimi poczucia braku ładu, przejrzystości i harmonii, co należy wiązać z nienarracyjnym, lecz symbolicznym charakterem omawianych przedstawień. Elementy przedmiotowe, przypominające raczej konstrukcje geometryczne usytuowane przypadkowo w nieokreślonej, bezprzedmiotowej przestrzeni, z pewnością czyniły oglądane ilustracje - w odczuciu badanych obrazami pozbawionymi cech klasycznie rozumianego piękna.

Nieliczni badani mieli trudność ze zwerbalizowaniem wrażenia, jakie wywarły na nich prezentowane ilustracje i w związku z tym (zapewne w poczuciu obowiązku podania jakiegokolwiek określenia) wymieniali jedynie elementy ich budowy formalnej, takie jak: „czerwone”, „symetryczne”, „niesymetryczne”, „kanciaste”.

Formułowane przez studentów określenia językowe analizowano także z uwzględnieniem konotacji emocjonalnych. Kategoryzowano je jako pozytywne, negatywne oraz pozbawione konotacji emocjonalnych. Ilustracje wykonane w niekonwencjonalnej dla wydawnictw dziecięcych stylistyce w świetle wartościowania leksykalnego studentów zyskały w przeważającej mierze (57\%) oceny o wydźwięku negatywnym oraz znikomą liczbę ocen pozytywnych (6\%). Blisko 40\% określeń nie niosło informacji o osobistym stosunku pozytywnym lub negatywnym do prezentowanych ilustracji. Jest to zrozumiałe ze względu na to, iż wiele $\mathrm{z}$ nich dotyczyło zawartych w przekazie wizualnym cech obiektywnych, zgodnych z charakterem iluminacji. Trudno więc $\mathrm{w}$ takiej sytuacji sądzić o osobistym stosunku badanych wobec nich.

\section{WARTOŚCIOWANIE LEKSYKALNE ILUSTRACJI REALISTYCZNEJ (WYIDEALIZOWANEJ)}

Seria o Martynce jest znana i niezwykle lubiana przez dzieci w wielu krajach. Sukces zapewnia serii prawdopodobnie stosowany przez ilustratora realizm, delikatnie 
deformowany idealizacją kształtów (dotyczy to m.in. twarzy przedstawianych postaci, które są nieskazitelne, pozbawione cech indywidualnych) oraz nienaturalną kolorystyką. Pastelowa kolorystyka iluminacji oraz ich łagodne światło sprawiają, iż ekspresję obrazu należy określić jako pogodną i przyjemną.

Tabela 2. Kategorie jednostek leksykalnych wartościujących ilustracje książki Martynka poznaje ptaki

\begin{tabular}{|c|c|c|c|c|}
\hline \multicolumn{2}{|c|}{ Kategoria oceny } & \multicolumn{2}{|c|}{$\mathbf{L}$} & $\%$ \\
\hline \multicolumn{2}{|l|}{ Wartość artystyczna } & \multicolumn{2}{|c|}{18} & 27 \\
\hline \multirow{2}{*}{ Wyraz artystyczny } & Nastrojowość & 26 & \multirow{2}{*}{34} & \multirow{2}{*}{51} \\
\hline & Metaforyczność & 8 & & \\
\hline \multicolumn{2}{|l|}{ Budowa formalna } & \multicolumn{2}{|c|}{10} & 15 \\
\hline \multicolumn{2}{|c|}{ Brak ocen/wyliczanie elementów formalnych } & \multicolumn{2}{|c|}{5} & 7 \\
\hline
\end{tabular}

Źródło: badania własne

Ilustracje pochodzące z książki Martynka poznaje ptaki wywoływały w głównej mierze oceny odnoszące się do wyrazu artystycznego przekazu wizualnego. Warto także podkreślić, że dotyczyły zwłaszcza jego nastrojowości (związanej z osobistymi odczuciami). Określenia formułowane przez studentów, takie jak: „słodkie”, „sympatyczne”, „urocze”, „miłe”, „wzruszające”, „ciepłe”, świadczą z jednej strony o tym, iż respondenci postrzegają infantylizm realistycznych i jednocześnie idealizujących rzeczywistość ilustracji, z drugiej zaś podzielają ich wydźwięk i akceptują go. Interesujące wydaje się także, iż wśród określeń dotyczących metaforyczności obrazów pojawiały się określenia sprzeczne, takie jak „realistyczne”, „rzeczywiste”, a równocześnie „bajeczne”, „magiczne”. Zapewne wynika to z postrzeganej przez badanych nienaturalności barw oraz charakterystycznego dla ilustratora „upiększania" przedstawień postaci ludzkich i zwierzęcych. Prawie co trzeci student odnosił się natomiast do wartości artystycznej ilustracji. W tym aspekcie badani ujmowali swoje odczucia w następujący sposób: „piękne”, „ładne”, „świetne”, „ciekawe”, „interesujące”, „okropne”, „nudne”. Dokonywali więc ogólnego wartościowania zwłaszcza w obszarze wartości estetycznych.

Niewielu studentów akcentowało cechy budowy formalnej oglądanych ilustracji, odnosząc się do sposobu stosowania kreski i plamy przez ilustratora oraz kompozycji: „wyraźne”, „przesadzone”. Znikoma liczba badanych formułowała określenia nieodnoszące się do czynników wartościowania plastycznego obiektu artystycznego (osoby te wskazywały cechy warstwy kolorystycznej: „pastelowe”, „kolorowe”).

Analiza jednostek leksykalnych ukierunkowana na odkrywanie osobistego stosunku badanych do ilustracji książki Martynka poznaje ptaki pozwoliła stwier- 
dzić, iż połowa $\mathrm{z}$ nich wyrażała pozytywne ustosunkowanie wobec stylistyki Marliera. Znaczna część pozostałych wyrażeń językowych uniemożliwiała dokonania kategoryzacji dychotomicznej. Zaledwie 4\% określeń studentów oceniono jako negatywne.

\section{WARTOŚCIOWANIE LEKSYKALNE ILUSTRACJI NOWOCZESNEJ (NAWIĄZUJĄCEJ DO MINIMALIZMU)}

Zgeometryzowane ilustracje Prawdziwej bajki sprawiają wrażenie niezwykle syntetycznego i symbolicznego ujęcia rzeczywistości. Płaskie przedstawienia wykorzystujące elementarne formy geometryczne oddają niejednokrotnie złożoność rzeczywistości trójwymiarowej. Zestawienie geometryzacji z triadą barw: żółtej, niebieskiej i czerwonej w towarzystwie czerni wyraźnie nawiązuje do stylistyki Bauhausu. Barwy plam są jednoznaczne, co potęguje wrażenie „plakatowego” schematyzmu przedstawień.

Informacje na temat liczebności ocen studentów poszczególnych kategorii wartościowania ilustracji Prawdziwej bajki zawarto w tabeli 4.

Tabela 4. Kategorie jednostek leksykalnych wartościujących ilustracje książki Prawdziwa bajka

\begin{tabular}{|c|c|c|c|c|}
\hline \multicolumn{2}{|c|}{ Kategoria oceny } & \multicolumn{2}{|c|}{$\mathbf{L}$} & $\%$ \\
\hline \multicolumn{2}{|l|}{ Wartość artystyczna } & \multicolumn{2}{|c|}{15} & 22 \\
\hline \multirow{2}{*}{ Wyraz artystyczny } & Nastrojowość & 4 & \multirow{2}{*}{29} & \multirow{2}{*}{44} \\
\hline & Metaforyczność & 25 & & \\
\hline \multicolumn{2}{|l|}{ Budowa formalna } & \multicolumn{2}{|c|}{6} & 9 \\
\hline \multicolumn{2}{|c|}{ Brak ocen/wyliczanie elementów formalnych } & \multicolumn{2}{|c|}{17} & 25 \\
\hline
\end{tabular}

Źródło: badania własne

Nowoczesne, a zarazem „wypowiadające się" symbolem ilustracje Prawdziwej bajki charakteryzowane były przez badane osoby przede wszystkim w wymiarze ich wyrazu artystycznego. Zrozumiałe wydaje się także, $\mathrm{z}$ uwagi na stylistykę obrazów książki, że najwięcej studenckich określeń dotyczyło cechy metaforyczności. Odnotowano tu następujące przymiotniki: „abstrakcyjne”, „minimalistyczne”, „schematyczne" (założono, że w kontekście percypowanych obrazów nie chodziło o powielanie wzorów ilustrowania, ale o formę przedstawień), „sztywne”, „proste”, „zaczarowane” (?), „magiczne” (?), ale także „szalone” i „dziwne”. Stosunkowo wielu badanych (25\%) w kontakcie z grafiką ilustracji nawiązujących do 
konstruktywizmu przedmiotowego formułowało określenia nieodnoszące się do wartościowania obrazów. Studenci wymieniali postrzegane elementy formalne ilustracji: „graficzne”, „figurzaste”, „wzorzyste”, „geometryczne”, „kolorowe”, „kolorystyczne”. Nieznacznie mniejsza liczba badanych wyrażała oceny dotyczące wartości artystycznych ilustracji. Swoje odczucia związane z prezentowanymi ilustracjami studenci określali następująco: „głupie”, „nieciekawe”, „ciekawe”, „zaskakujące”, „intrygujące”, „brzydkie”, „beznadziejne”. Określenia formułowane przez studentów wyraźnie sugerują, iż większość z nich w sposób uogólniony akcentowała semantyczną wymowę ilustracji. Nieliczne sformułowania studentów dotyczyły budowy formalnej iluminacji, tj. ich koncepcji artystycznej („nowoczesne”, ,awangardowe”) oraz wewnętrznej organizacji („niezrozumiałe”).

Odnotowana znaczna liczba jednostek leksykalnych odnoszących się do oceny stopnia metaforyczności obrazów ilustracji oraz określeń uniemożliwiających wskazanie konkretnych czynników ich oceny skutkowały tym, iż niewiele (45\%) określeń niosło informację o akceptacji lub negacji prezentowanych iluminacji. Spośród wszystkich wyrażeń formułowanych przez badanych 37\% miało wyraźnie pejoratywny wydźwięk, a zaledwie $8 \%$ wszystkich wyrażeń dotyczących ilustracji Prawdziwej bajki miało pozytywne asocjacje. Należy jednak podkreślić, że odnotowane w tym przypadku przymiotniki, takie jak: „zaskakujące”, „ciekawe”, „intrygujące”, można lokalizować w obszarze wartości poznawczych. Może nieco dziwić, że w odniesieniu do omawianych ilustracji nie pojawiły się żadne wyrazy wartościujące o pozytywnych konotacjach, charakterystyczne dla wartościowania estetycznego.

\section{WARTOŚCIOWANIE LEKSYKALNE ILUSTRACJI BAJKOWEJ (Z OBSZARU KICZU)}

Ilustracje książeczki Sposób na laleczkę stanowią konwencję, z którą mali adresaci oraz dorośli pośrednicy są oswojeni. Infantylizacja rzeczywistości książkowej dominuje w dużej liczbie publikacji dla najmłodszych dostępnych w księgarniach, ale i punktach taniej książki czy w marketach. Należy bowiem podkreślić, że wykorzystywane w przygotowywaniu warstwy graficznej tego typu wydawnictw wzorce kształtów przez wielokrotne kopiowanie obniżają koszty wydawnicze, co pociąga za sobą dużą ich dostępność (ze względu na cenę). Ponadto zazwyczaj łatwa (bo dosłownie ilustrująca treść tekstu) i „ładna” (bo krzykliwa kolorystycznie i idealizująca świat) ilustracja często skłania dorosłego do zakupu określonej książeczki i wręczenia jej dziecku. 
Tabela 5. Kategorie jednostek leksykalnych wartościujących ilustracje książki Sposób na laleczkę

\begin{tabular}{|c|c|c|c|c|}
\hline \multicolumn{2}{|l|}{ Kategoria oceny } & \multicolumn{2}{|c|}{$\mathbf{L}$} & $\%$ \\
\hline \multicolumn{2}{|l|}{ Wartość artystyczna } & \multicolumn{2}{|c|}{12} & 18 \\
\hline \multirow{2}{*}{ Wyraz artystyczny } & Nastrojowość & 24 & \multirow{2}{*}{29} & \multirow{2}{*}{44} \\
\hline & Metaforyczność & 5 & & \\
\hline \multicolumn{2}{|l|}{ Budowa formalna } & \multicolumn{2}{|c|}{5} & 7 \\
\hline \multicolumn{2}{|c|}{ Brak ocen/ wyliczanie elementów formalnych } & \multicolumn{2}{|c|}{21} & 31 \\
\hline
\end{tabular}

Źródło: badania własne

Ilustracje bajkowe, charakteryzujące się elementami typowymi dla wytworów sztuki kiczowatej (krzykliwość barw, powtarzalność wzorów, idealizacja fałszująca rzeczywistość) koncentrowały uwagę studentów przede wszystkim na nastrojowości (wyraz artystyczny). Ich pogodny a zarazem infantylny wydźwięk miał odzwierciedlenie w następujących wyrażeniach formułowanych przez badanych: „słodkie”, „miłe”, „wesołe”, „zabawne”, „śmieszne”, „przyjemne”. W kategorii leksykalnych ocen związanych z wyrazem artystycznym mieszczono także określenie „bajkowe”, oddające charakter zastosowanej przez ilustratorów formy wypowiedzi plastycznej. Wiele spośród odnotowanych określeń związanych z ilustracjami książki Sposób na laleczkę nie odnosiło się do przyjętych kategorii ocen, gdyż badani często wskazywali adresata, pisząc: „dla dzieci”, „dziecięce”, a także akcentowali wielobarwność iluminacji („kolorowe”, „bardzo kolorowe”). Nieliczni studenci ujmowali doświadczane odczucia $\mathrm{w}$ kategoriach wartości artystycznych. Ci badani uznali percypowane ilustracje za „ciekawe”, „fajne”, „ładne”, ale także „nudne”. Zaledwie kilka osób natomiast oceniło je, odnosząc się do budowy formalnej obrazów, zwracając uwagę, iż są one „tradycyjne” i „klasyczne”, a więc wykonane w znanej i oswojonej przez badanych stylistyce.

Analiza określeń dotyczących bajkowych ilustracji dowodzi, że są one preferowane przez znaczną liczbę badanych studentów, gdyż aż 57\% ocen wartościujących miało wydźwięk pozytywny, a jedynie około 1\% negatywny. Pozostałe określenia uniemożliwiały ustalenie stosunku badanych do prezentowanych im ilustracji.

\section{PODSUMOWANIE}

Zbiorcze zestawienie wyników dotyczących liczby jednostek leksykalnych określonych kategorii wartościujących ilustracje książkowe pozwala ustalić, jakie obszary kulturowego przekazu wizualnego są postrzegane i oceniane przez studentów, którzy wkrótce pełnić będą rolę pośrednika między dzieckiem a książką. 


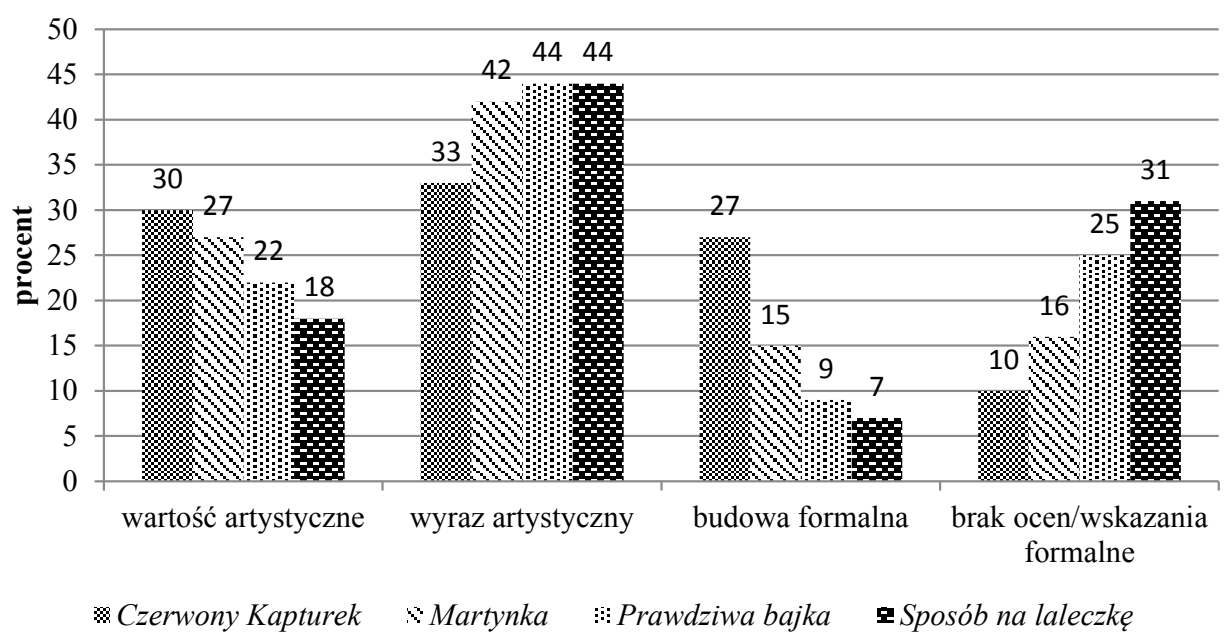

Rysunek 1. Kategorie wartościujących jednostek leksykalnych a rodzaj ilustracji Źródło: badania własne

Zestawienie zbiorcze rezultatów analiz szczegółowych, dotyczących oceny prezentowanych w badaniach ilustracji książek dla dzieci, wyraźnie wskazuje, iż najwięcej spośród nich odnosiło się do kategorii ocen związanych z wyrazem artystycznym iluminacji. Jak widać, dotyczy to wszystkich czterech konwencji ilustratorskich. Badani studenci określając swoje odczucia/wrażenia w kontakcie z prezentowanymi ilustracjami, najczęściej zwracali uwagę na ich nastrojowość oraz stopień metaforyczności czy też komunikatywności. Znamienne jest, iż ilustracje stanowiące obrazy przedstawiające, a więc „przedmiotowe” (ukazujące z wysokim stopniem dokładności i rzetelności przedmioty rzeczywiste i fantastyczne) prowokują ocenianie w obszarze nastrojowości (Martynka poznaje ptaki i Sposób na laleczkę). Natomiast ilustracje nowoczesne, oparte na schematycznych znakach ikonicznych (Prawdziwa bajka) oraz oscylujące między przedmiotowością a bezprzedmiotowością (Czerwony Kapturek) koncentrują uwagę odbiorców na sposobie ujęcia rzeczywistości książkowej.

Liczba ocen wartościujących kolejnych kategorii była zróżnicowana w odniesieniu do rodzaju ilustracji. W kategorii związanej z wartością artystyczną oraz budową formalną obrazów najczęściej sytuowano określenia studentów dotyczące ilustracji Czerwonego Kapturka, najrzadziej zaś wyrażenia związane z iluminacjami Sposobu na laleczkę. Interesujące wydaje się, że właśnie w odniesieniu do tych ostatnich badani stosunkowo często formułowali określenia, które uniemożliwiały lokowanie ich w wyróżnionych kategoriach wartościowania obrazów. Odnosi się 
wrażenie, że badane osoby unikały wyrażania osobistego stosunku do prezentowanych obrazów, zastrzegając, że nie one są ich adresatami, lecz dzieci.

Wyniki dotyczące konotacji (pozytywnych i negatywnych) korpusu leksykalnego wartościującego cechy iluminacji książkowych ujawniają ciekawą tendencję. Najwięcej przychylnych (i znikomą liczbę nieprzychylnych) reakcji werbalnych badanych studentów zyskały ilustracje realistyczne wyidealizowane oraz bajkowe o niskich walorach artystycznych. Warto przypomnieć, że obie stylistyki (Martynka poznaje ptaki i Sposób na laleczkę) - choć w różnym stopniu - egzemplifikują cechy kiczu (idealizacja rzeczywistości, akademizm, powtarzalność form, nienaturalna kolorystyka, „krzykliwości” przekazu wizualnego). Jednak podkreślenia wymaga fakt, że ilustracje Marliera świadczą o jego doskonałym warsztacie technicznym i wypracowaniu rozpoznawalnego stylu, natomiast ilustracje Stefaniaków to komputerowo generowane i przeklejane wzorce, pozbawione oryginalności.

Odwrotna sytuacja dotyczy ilustracji przygotowanych w konwencjach nowoczesnych, awangardowych. W odniesieniu do nich bowiem spośród całego związanego z nimi korpusu leksykalnego odnotowano ponad 50\% jednostek leksykalnych z oceną negatywną, wpisaną w ich strukturę semantyczną. Można więc sądzić, że eksperymenty ilustratorskie (notabene wysoko oceniane przez osoby profesjonalnie związane z twórczością ilustratorską dla dzieci) nie spotykają się ze zrozumieniem młodych ludzi aspirujących do pełnienia roli nauczyciela wczesnej edukacji.

Podsumowując, najważniejsze spostrzeżenia dotyczące wartościowania leksykalnego wykorzystanych $\mathrm{w}$ badaniach ilustracji książkowych sprowadzają się do następujących stwierdzeń:

- kategorie studenckich ocen ilustracji dotyczyły najczęściej wyrazu artystycznego przekazów wizualnych, a zwłaszcza ich nastrojowości i sposobu obrazowania w odniesieniu do stopnia abstrakcyjności:

- formułowanie przez badanych studentów określeń odwołujących się do leksyki wartości emocjonalnych (najczęściej pozytywnych), prowokowane było najczęściej ilustracjami określanymi jako łatwe, idealizujące i infantylizujące oferowaną dziecku rzeczywistość książkową; z jednej strony może to oznaczać przychylność przyszłych pedagogów wobec stylistyki postrzeganej jako pożądana z perspektywy potrzeb dzieci, jak również stanowić wyraz autentycznych upodobań obrazowych studentów;

- formułowanie przez badanych studentów określeń, zmierzających do obiektywizacji konwencji plastycznej ilustracji w kategorii sposobu przedstawienia treści, najczęściej związane było z iluminacjami o cechach awangardowej sztuki w zakresie ilustracji dla dzieci;

- zgromadzony korpus leksykalny ujawnił ubóstwo i często potoczność słownictwa z obszaru wartościowania wytworów plastycznych; 
- oceny ilustracji formułowane przez studentów często zawierały ich waloryzację:

- studenci ujawnili preferencje obrazowania mimetycznego, figuratywnego i jednocześnie $\mathrm{z}$ obszaru sztuki związanej z kiczem, a wobec rozwiązań nowatorskich, trudniejszych, bo nieoczywistych i nawiązujących do cech nurtów modernistycznych, nierzadko wykazywali niechęć i negatywną krytykę.

Zrelacjonowane badania pokazują dość niezadowalające kompetencje młodych ludzi przygotowujących się do zawodu nauczycielskiego w zakresie sztuk wizualnych. Wyrazem tego jest choćby wąski i często wzięty z potocznej mowy zasób słownictwa z obszaru wartościowania wytworów plastycznych czy też brak umiejętności werbalizowania odczuć związanych z percepcją przekazu wizualnego. Sytuacja ta prawdopodobnie jest skutkiem ubogich doświadczeń w zakresie obcowania $\mathrm{z}$ wizualnymi tekstami, ale także efektem edukacji w zakresie plastyki i wiedzy o kulturze. Odnosi się wrażenie, że rezultaty badań Marii Brody-Bajak (2009, s. 232-236), dotyczące opinii młodych ludzi (w wieku od 16 do 24 lat) na temat szkolnej edukacji artystycznej, odzwierciedlają realny i powszechny problem. Większość osób badanych przez autorkę twierdziła, iż doświadczenia z lekcji artystycznych przedmiotów nie pozostawiły większego śladu w ich życiu oprócz „szczątkowych” korzyści. Były nimi: znajomość podstawowych technik plastycznych i wybranych nurtów sztuki plastycznej (przy czym osobistą wiedzę z historii sztuki respondenci uznali za „mglistą”), a także znajomość kilku piosenek i zasad gry na flecie prostym. Poważną refleksję i natychmiastową rewizję praktyki edukacyjnej $\mathrm{w}$ omawianym obszarze powinna wzbudzić ocena szkolnego kształcenia w ramach przedmiotów artystycznych dokonana przez tychże badanych, ujęta w słowach: „kupa śmiechu - i nic więcej” oraz „zawężenie poczucia piękna” (Broda-Bajak 2009, s. 236). Autorka eksploracji odnotowała tylko nieliczne pochlebne opinie dotyczące znaczenia edukacji artystycznej, w których respondenci akcentowali jej znaczenie w rozbudzeniu zainteresowania sztuką.

Podobnie niepokojącą diagnozę uzyskano w efekcie realizacji projektu „Profesjonalizm w edukacji. Przygotowanie i realizacja nowego programu praktyk pedagogicznych na Wydziale Artystycznym UMCS” (Boguszewska, Stępnik, Tarasiuk 2013). Podjęte w jego ramach badania dotyczyły stanu wiedzy o sztuce i kulturze plastycznej oraz muzycznej uczniów kształconych zgodnie z podstawą programową obowiązującą w latach 1999-2010. Obejmowały one uczniów kończących klasę szóstą (lub rozpoczynających naukę w gimnazjum), kończących gimnazjum (lub rozpoczynających naukę w szkole średniej) oraz kończących szkołę średnią (lub rozpoczynających pierwszy rok studiów). Ustalony w toku badań stan wiedzy badanych na temat sztuki i kultury plastycznej (oraz muzycznej) pozwolił autorom 
określić poziom kompetencji kulturalnych, który okazał się zaskakująco niski we wszystkich badanych grupach. W zakresie treści związanych z podstawami plastyki (znajomość kategorii barw, kompozycji, dziedzin sztuki) oraz historii sztuki (znajomość kierunków sztuki plastycznej, identyfikowanie dzieł) badani studenci uzyskiwali zaledwie od 6 do $4 \%$ z maksymalnej liczby punktów, a ich osiągnięcia były zbliżone do rezultatów gimnazjalistów.

W związku z tym warto wytrwale powracać do słów Stefana Szumana, który pisał wiele lat temu:

[...] język dzieł sztuki - mimo swej wymowy, konkretności oraz nieomylnej trafności w przedstawianiu treści - nie jest dla każdego od razu zrozumiały. Tego swoistego języka - innego od wszystkich języków - trzeba się nauczyć, aby w pełni wyczerpać i przeżyć treść, którą wyraża. Należy się go uczyć stopniowo, starannie, wnikliwie, tak jak każdego języka (Szuman 1969, s. 21).

Opierając się na analogii autora, można dopełnić jego myśl spostrzeżeniem, że tak jak dziecko absorbuje w sposób nieświadomy, bez większego wysiłku mowę otoczenia, w którym funkcjonuje, a potem $\mathrm{z}$ dnia na dzień spontanicznie samo zaczyna posługiwać się nią, tak obcowanie i stopniowe oswajanie się z "mową" przekazów wizualnych stanowi istotny warunek jej opanowania. A co ważne, nie można zatrzymać się na etapie poznawania zasadniczych znaków plastycznych, tak jak na nabywaniu słownictwa i podstaw gramatyki. By móc uczestniczyć w komunikacji z artystą-plastykiem, niezbędne jest pogłębianie kompetencji umożliwiających nie tylko odczytywanie treści wytworów sztuki, ale także zrozumienia związku cech formalnych z kontekstem znaczeniowym.

\section{LITERATURA}

Boguszewska A., Stępnik M., Tarasiuk R., 2013, Stan wiedzy o sztuce i kulturze plastycznej i muzycznej uczniów kształconych według podstawy programowej obowiązujacej w latach 1999-2010. Raport $z$ badań. Lublin, Wydawnictwo UMCS.

Boguszewska A., 2008, Ksiażka obrazkowa i ksiażka z obrazkami dla dzieci a zagadnienie kiczu w sztuce. W: K. Krasoń, B. Mazepa-Domagała (red.), Wyrazić i odnaleźć siebie, czyli o sztuce, ekspresji, edukacji i arteterapii. Katowice-Mysłowice, Górnośląska Wyższa Szkoła Pedagogiczna im. Kardynała Augusta Hlonda.

Broda-Bajak M., 2009, Młodzi i sztuka w rzeczywistości medialnej i globalizacji kultury. W: R. Ławrowska, B. Muchacka (red.), Edukacja artystyczna a rzeczywistość medialna. Kraków, Wydawnictwo Naukowe Uniwersytetu Pedagogicznego. 
Cackowska M., 2009, Czym jest książka obrazkowa? Część pierwsza. „Ryms”, nr 5. Cackowska M., 2009, Czym jest książka obrazkowa? Część druga. „Ryms”, nr 6.

Cackowska M., 2009/2010, Czym jest książka obrazkowa? Część druga. Problemy z pojmowaniem książki obrazkowej w Polsce. „Ryms”, nr 8.

Centner-Guz M., 2016, The Lexical Evaluation of Children's Book Illustrations by Pedagogy Students. W: M. Chepil, A. Żukowska, O. Karpenko (red.), In the Sphere of Education and Artist Work. Drohobych, Publishing department of Drohobych Ivan Franko State Pedgogical University.

Choynowski M., 1967, Wymiary malarstwa. „Studia Estetyczne”, nr 4.

Laskowska E., 1992, Wartościowanie w języku potocznym. Bydgoszcz, Wydawnictwo Uczelniane WSP w Bydgoszczy.

Petruk E., Waligórska A., 2013, Sztuka, wiedza i opowieść. Wpływ obecności i charakteru tekstu nt. dzieła sztuki na ocenę prezentowanej kompozycji. W: B. Bokus, Z. Kloch (red.), Teksty i interpretacje. Język - poznanie - komunikacja, t. 17. Piaseczno, Wydawnictwo LEXEM.

Podstawa programowa kształcenia ogólnego dla gimnazjów i szkół ponadgimnazjalnych, których ukończenie umożliwia uzyskanie świadectwa dojrzałości po zdaniu egzaminu maturalnego (Dz.U. z 2012 r. poz. 977), opublikowano: http://bip.men. gov.pl/images/stories/akty/27_08.pdf [dostęp: 30.06.2015].

Strzałecki A., 2006, Wymiary reprezentacji poznawczych dzieł twórczych. Ujęcie poznawczej psychologii twórczości. „Zagadnienia Naukoznawstwa”, nr 2.

Szuman S., 1969, O sztuce i wychowaniu estetycznym. Warszawa, PZWS.

Wiercińska J., 1986, Sztuka książki. Warszawa, PWN.

Zabawa K., 2013, Rozpoczęta opowieść. Polska literatura dziecięca po 1989 roku wobec kultury współczesnej. Kraków, Akademia Ignatianum, Wydawnictwo WAM.

\title{
VALUING ILLUSTRATIONS IN CHILDREN'S BOOKS BY PEDAGOGICAL STUDENTS. CATEGORIES OF SELECTED ILLUSTRATION SOLUTIONS
}

\begin{abstract}
Picture books and illustrations provide children fine art contact and first visual communication experience. Therefore, it is important for them to have their place in the child's daily routine and to be valuable in terms of cognitive and aesthetic stimuli. A place where a toddler can experience them - next to the family home - is a kindergarten, so teachers should have the competence to introduce a child into the world of book illustration. Above all, teachers ought to express personal involvement in the evaluation of such cultural texts. The paper outlines the value of book illustrations which are perceived and preferred by people who are preparing for the profession of early childhood education teacher. The subjects assessed illustrations made in different conventions and stylistics (realistic and fantastic, classic
\end{abstract}


and avant-garde) and made with various techniques (painting and graphic). The assembled lexical corpus, perceiving perceptions of the illustration, was analysed from the perspective of the category of paintings evaluation and the lexical assessment category, which expressed a personal attitude to the perceived images.

Keywords: picture book for children, illustrated book for children, pedagogy students, valuing illustrations 